\title{
ENVIRONMENTALLY SOUND SPATIAL MANAGEMENT USING CONSERVATION AND LAND EVALUATION APPROACH AT SLOPING LANDS IN HUMID TROPIC (A CASE STUDY OF ANTANG KALANG SUB-DISTRICT, CENTRAL KALIMANTAN, INDONESIA)
}

\author{
Andy Bhermana* and Susilawati \\ Assessment Institute for Agricultural Technology of Central Kalimantan, Indonesia \\ Submitted: 2018-09-14 Accepted: 2019-05-06
}

\begin{abstract}
The main problem faced by sloping lands in the humid tropic includes land degradation influencing natural ecosystem damage broadly. Land conversion and improper land-use have been widely recognized as the main cause of environmental damage since the demands for agricultural lands become greater than land resource available. The objective of this study was to determine the concept of appropriate land-use planning through environmentally sound spatial management in order to prevent land and environmental degradation. The sub-district of Antang Kalang was chosen as study area representing sloping lands in humid tropic that have a susceptibility to erosion. Conservation approach by the use of USLE erosion risk prediction model and land evaluation through land suitability classification was used in this study. The geographic information system (GIS) and remote sensing (RS) technology were applied to generate spatial basic information and to assist in spatial analysis. Two crops, upland rice, and rubber, representing food crop and estate $p$ have been selected based on the local resource that has been existed since a long time ago. The result of spatial analysis shown that the arable land for agricultural practices covers 9,039 hectares $(23.19 \%)$ while for non-arable land, it is allocated for forest preservation with total areas 29,934 hectares (76.81\%). Land-use planning and land resources management involving conservation aspect and land suitability evaluation should be taken into account for farming practice at sloping lands areas since the value of soil loss potential appears as an indicator of erosion risk. Permanent cultivation system and the intercropping farming system is the option of recommended agricultural practice at sloping lands in the humid tropic that have a susceptibility to erosion.
\end{abstract}

Keywords: Land-use, Planning, Management, Land suitability, Conservation

How to Cite: Bhermana, A., and Susilawati. (2019). Environmentally Sound Spatial Management Using Conservation and Land Evaluation Approach at Sloping Lands in Humid Tropic (A Case Study of Antang Kalang Sub-District, Central Kalimantan, Indonesia). Sains Tanah Journal of Soil Science and Agroclimatology, 16(1): 76-89 (doi: 10.20961/stjssa.v16i1.24004)

Permalink/DOI: http://dx.doi.org/10.20961/stjssa.v16i1.24004

\section{INTRODUCTION}

In Central Kalimantan, Indonesia, mostly, the demands for agricultural lands become greater than land resource available.

\footnotetext{
* Corresponding Author:

Email:andybhermana@yahoo.com
}

This reasonable opinion appears since many land-use allocations ignore appropriate landuse for forestry and wildlife as well. With a population density of 16 people $\mathrm{km}^{-2}$ (BPS Provinsi Kalimantan Tengah, 2017), in general, a land resource that is still available should then be managed with environmentally sound 
spatial management. In order to ensure land resources can be used for the future generation, on the basis of natural environment condition and capability of land resources, agricultural land-use must not be on increased agricultural productivity solely, but rather on sustainable development that is appropriate to the environment.

Appropriate land-use planning is then required in order to achieve long-term sustained yields involving the successful management of resources for agricultural lands to satisfy changing human needs while maintaining and enhancing the quality of the environment and conserving natural resources (Hoffman, 2017; Altieri, 1992). Planning is underpinned by the assumption that adequate information exists for those exercising public authority to make decisions regarding the best use of land in the future (Flaherty \& Smit, 1982) and is concerned with sustainable land-use allocation (Garcia et al., 2017) and it must be based on an understanding both of the natural environment and of the kinds of land-use envisaged (FAO, 1976). The function of landuse planning for agricultural purposes is, therefore, to guide decisions on land-use in such way that the resources of environment are put to the most beneficial use, while at the same time conserving those resources for the future.

The main problem related to land resources and natural environment as well that is still found in Central Kalimantan involve improper land-use doing simultaneously with deforestation. Initially, land-use changes are the impact of the existence of shifting cultivation as traditional agriculture system (Mulyoutami et al., 2010). The present main issues include land-use expansion for the estate. Massively, opening new lands for oil palm plantation has been practiced since 2005 when the local government established that estate development is one of the leading sectors of regional development.

The land conversion due to opening new lands for agricultural purposes tend to have a negative impact on the natural environment. In central to northern part Central Kalimantan, mainly dominated by acid tropical soils at sloping lands, unfavorable soils development process occurs since the lands were cultivated inappropriately for agriculture, plantation, mining, and transmigration as well (Angi \& Wiati, 2017; Gay-des-Combes et al., 2017). Because of its susceptibility of erosion, many agricultural practices lead to land degradation and soil erosion especially at sloping areas (Espinosa et al., 2017; van Uexkull \& Bosshart, 1989; Notohadiprawiro, 1989).

The sub-district of Antang Kalang located in Central Kalimantan was selected as a study area because it represents relevant issues concerning land resource availability including its natural environment and local resource that should be preserved. Further land degradation and environmental damage including soil erosion, deforestation, and loss of genetic resource should then be prevented in order to conserve the quality of the environment.

The objectives of this study were to provide basic concepts of environmentally sound spatial management through appropriate land-use planning on the basis of local resource and long-term use and yields. The aspect of conservation and land evaluation approach was used in order to determine the spatial concept as basic plans. The geographic information system (GIS) and remote sensing (RS) technology were applied to generate spatial basic information and to assist spatial analysis.

\section{MATERIAL AND METHODS \\ General Overview of Study Area}

The study area is focussed on Antang Kalang sub-district, Central Kalimantan 
province, Indonesia with total areas 38,973 hectares (Figure 1). It is situated between latitudes $01^{\circ} 11^{\prime} 41^{\prime \prime} \mathrm{S}$ and $01^{\circ} 27^{\prime} 14^{\prime \prime} \mathrm{S}$ and longitudes $112^{\circ} 27^{\prime} 07^{\prime \prime} \mathrm{E}$ and $112^{\circ} 49^{\prime} 45^{\prime \prime} \mathrm{E}$. This site location is classified into a humid tropical region because of its geographical position located below the equatorial line with humid climate system and rainfall distribution throughout the years (Wohl et al., 2012).

Administratively, this area belongs to Antang Kalang sub-district, Kotawatingin Timur regency. Inside the location, there are only 5 groups of settlement, known as village, namely Tumbang Ngahan, Tumbang Ramei, Tumbang Hejan, Tumbang Nusa and Tumbang Gagu. They are located at river stream areas with a total population of 1,569 persons and mostly dominated by Dayak tribe for these five villages. With the density of 4 persons $\mathrm{km}^{-2}$, it reflects that in general, the lands are still widely available related to land-use for human living.

The majority of the Dayak community in this site location work as farmers and traditional farming used to agricultural practice is shifting cultivation. Some of them spend time with latex rubber tapping, hunting, and traditional mining. These daily activities have been carried out since a long time ago, derived from their ancestor in the past.

The climatic condition of study areas generally determined by its geographical position on the equator and it is categorized into the humid tropical region, characterized by a rather constant temperature throughout the year, high humidity and high precipitation (Loo et al., 2015). Based on available nearest climate station records located in Katingan around 103 kilometers from the center of the study area, it has annual rainfall around 2947 $\mathrm{mm}$. The rainy season starts from October to May while the dry season runs from June to September. The relative humidity is about $77 \%$ with mean temperature $30^{\circ} \mathrm{C}$. Additional information for climate can be obtained from Oldeman Agroclimatic Zone (1980) and it shows that study area falls within climatic zone $A$ according to the Oldeman system. It implies that the number of consecutive wet months is $>$ 9 months and consecutive dry months less than 2 months.

The typology of land in the study area classified into upland with specific acid tropical soils that have low fertility status and susceptible to erosion (Suharta, 2010; Amien, 1990). There are three soil great groups found in the site study location, namely, Paleudults, Hapludults, and Dystrudepts. These tropical soils are the products of rapid weathering and strong leaching, so that, most of these soils would probably be best left under forest (Suharta, 2010; van Uexkull \& Bosshart, 1989).

The methodology used in this study was the implementation of soil erosion prediction model and land resource evaluation. Soil erosion prediction model is applied to determine areas susceptible to erosion spatially. The universal soil loss equation (USLE) with mathematical formula by multiplying several factors involving rainfall erosivity, soil erodibility, slope, land cover, and conservation practice to determine the value of average soil loss due to land surface erosion (ton ha- ${ }^{1}$ year $^{-1}$ ) (Wischmeier \& Smith, 1978). While for land evaluation, the procedure refers to The "FAO Framework for Land Evaluation" through the matching process between land parameters with crop requirements leads to an assessment of the suitability of land-use for the crop (FAO, 1976; Wahyunto et al., 2016; Sys et al., 1993). The resulting evaluation was, therefore, then integrated into a GIS environment for further spatial analysis using qualitative descriptive analysis procedure.

The GIS technology was applied to generate spatial data as part of geospatial information based on the result of USLE calculation and land evaluation. In addition to 
spatial analysis purposes, GIS was also applied to facilitate, improvement, storing, displaying, future utilization, and updating data (Abdel Rahman et al., 2016; Andy et al., 2002; Eswaran et al., 1992; Goodchild et al., 1992; Tomlinson, 1968). Furthermore, the RS technology was also used in this study mainly to identify land cover, present land-use, and digital elevation model (DEM) that represent basic factors for conservation aspects including soil erosion prediction model.

Basic data and information as datasets consist primarily of spatial data and tabular data obtained from field survey and literature study involving soil maps, climatic maps, land characteristics, and land-use requirements. These data were used for both land conservation analysis and land resource evaluation purpose. Two crops, upland rice and rubber, representing food crop, and estate $p$ have been selected based on a local resource that have been existed since a long time ago.

The other primary data include a) Landsat imagery accessed from Landsat 8 with a resolution of 30 meters on March 2016 considering the minimum cloud-covered for the study area (Sitanggang, 2010) and b) DEM data taken from SRTM 30 meters (Smith \& Sandwell, 2003). These data were mainly used to understand the land cover spatial pattern and landform characteristics that have a close relation to soil erosion risk level and land evaluation as well. Further support data was also completed through field survey. PC-based GIS and RS software for data interpretation and spatial analysis used in this study were ErMapper, Global Mapper, and Arc View. An overview of general methodological steps is provided in Figure 2.

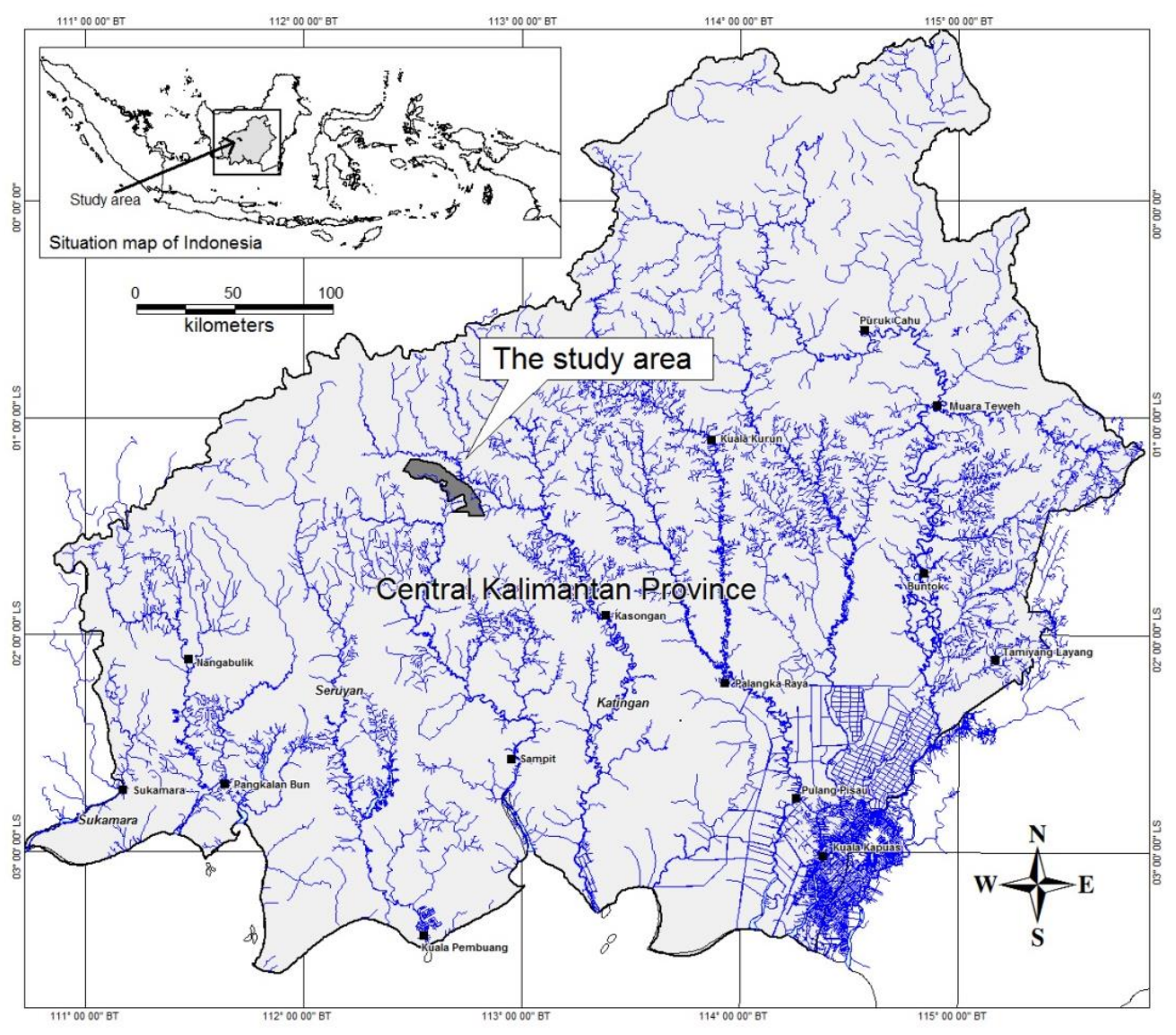

Figure 1. The map of situation showing location of study 


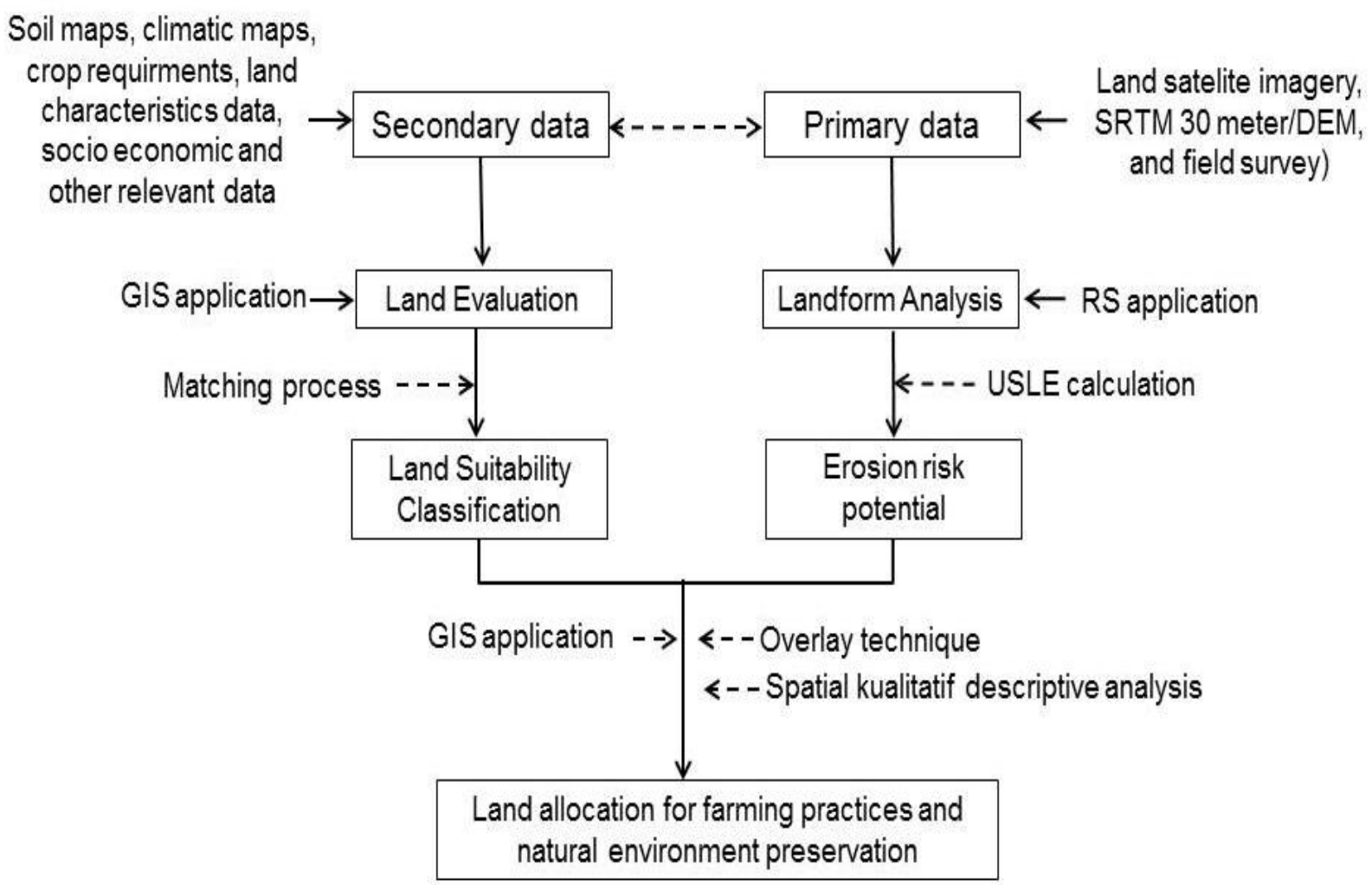

Figure 2. An overview of general methodological steps

The discussion about landform and natural feature of the earth's surface in this study is mainly based on DEM data interpretation taken from SRTM 30 meters. The result of interpretation using remote sensing (RS) technology application and field ground check showed that the study area is categorized into sloping land with altitude ranging from 52.03 meters to 445.79 meters above sea level. As hilly areas, there are three major landform of undulating plains, moderately steep hills, and hillocky plains that cover this site location.

\section{RESULTS}

Based on DEM data interpretation, the study areas were mainly categorized into sloping land. It has been proven by the display of slope shader based on DEM (Figure 3). This data was then interpreted to provide spatial data of contour including elevation and slope gradient (Figure 4). The result of further interpretation and spatial analysis, therefore, showed that this area is geographically divided into 3 slope classes i.e 4-8\%; $16-25$ and 26-40 (Figure 5) including each total areas (Table 1).

Table 1 shows that the study area is mainly dominated by the slope class of $16-25 \%$ with total area 28,988 hectares (74.37\%). Although the land could be suitable for agricultural practice, landform description should be taken into account especially for conservation aspects because the slopes greater than $8 \%$ is being prone to erosion (Angima et al., 2003). However, the remaining lands with slope $4-8 \%$ that constitute about $23.19 \%$ of total study area have the potential to be developed. 
Table 1. The classification of slope and landform description for the study area

\begin{tabular}{|c|c|c|c|c|}
\hline \multirow[t]{2}{*}{ No } & \multirow{2}{*}{$\begin{array}{l}\text { Slope class } \\
(\%)\end{array}$} & \multirow[t]{2}{*}{ Landform } & \multicolumn{2}{|c|}{ Areas } \\
\hline & & & (Hectares) & (\%) \\
\hline 1 & $4-8$ & Undulating plain & 9,039 & 23.19 \\
\hline 2 & $16-25$ & $\begin{array}{l}\text { Moderately steep hills, hills with a moderately steep } \\
\text { dip and steep scar }\end{array}$ & 28,988 & 74.37 \\
\hline \multirow[t]{2}{*}{3} & $26-40$ & Steep narrow ridges & 946 & 2.43 \\
\hline & & Total & 38,973 & 100.00 \\
\hline
\end{tabular}

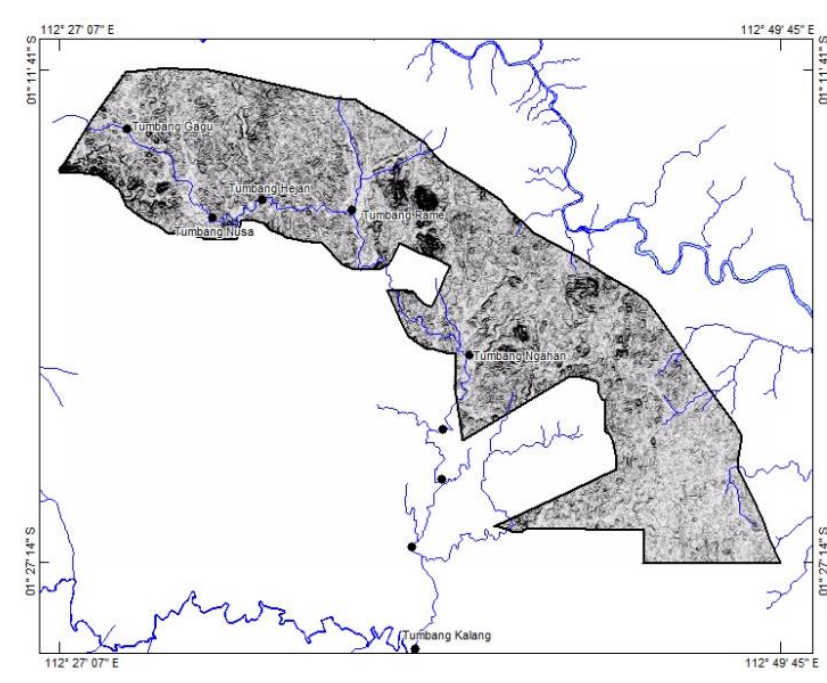

Figure 3. The view of slope shader based on DEM

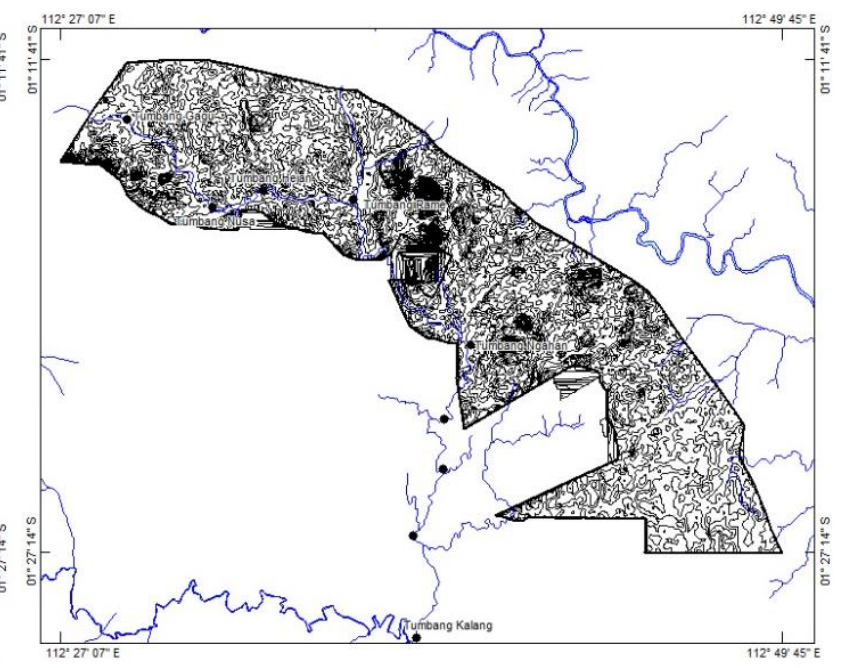

Figure 4. The map of contour with interval of $20 \mathrm{~m}$

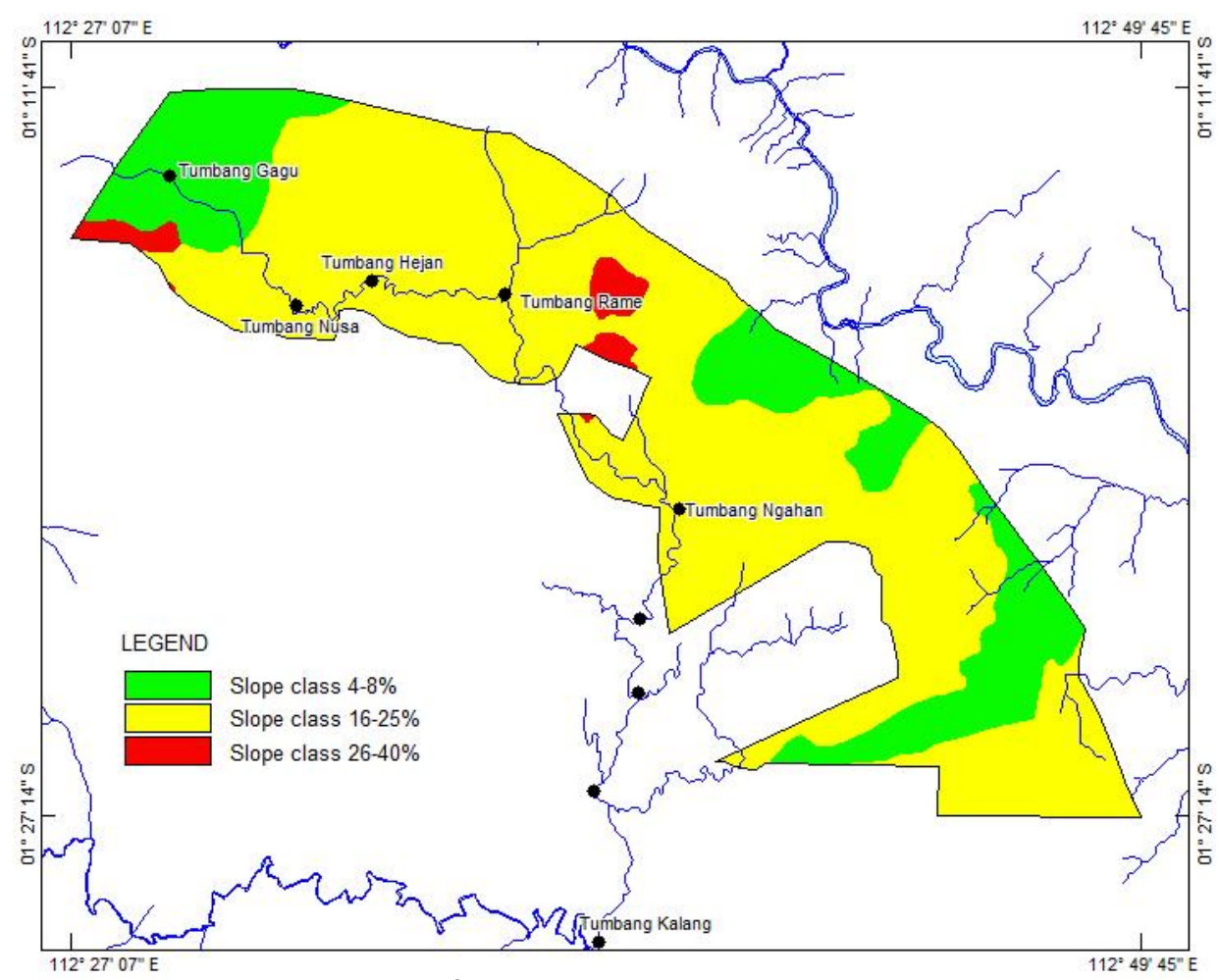

Figure 5. The map of slope class distribution in the study area 


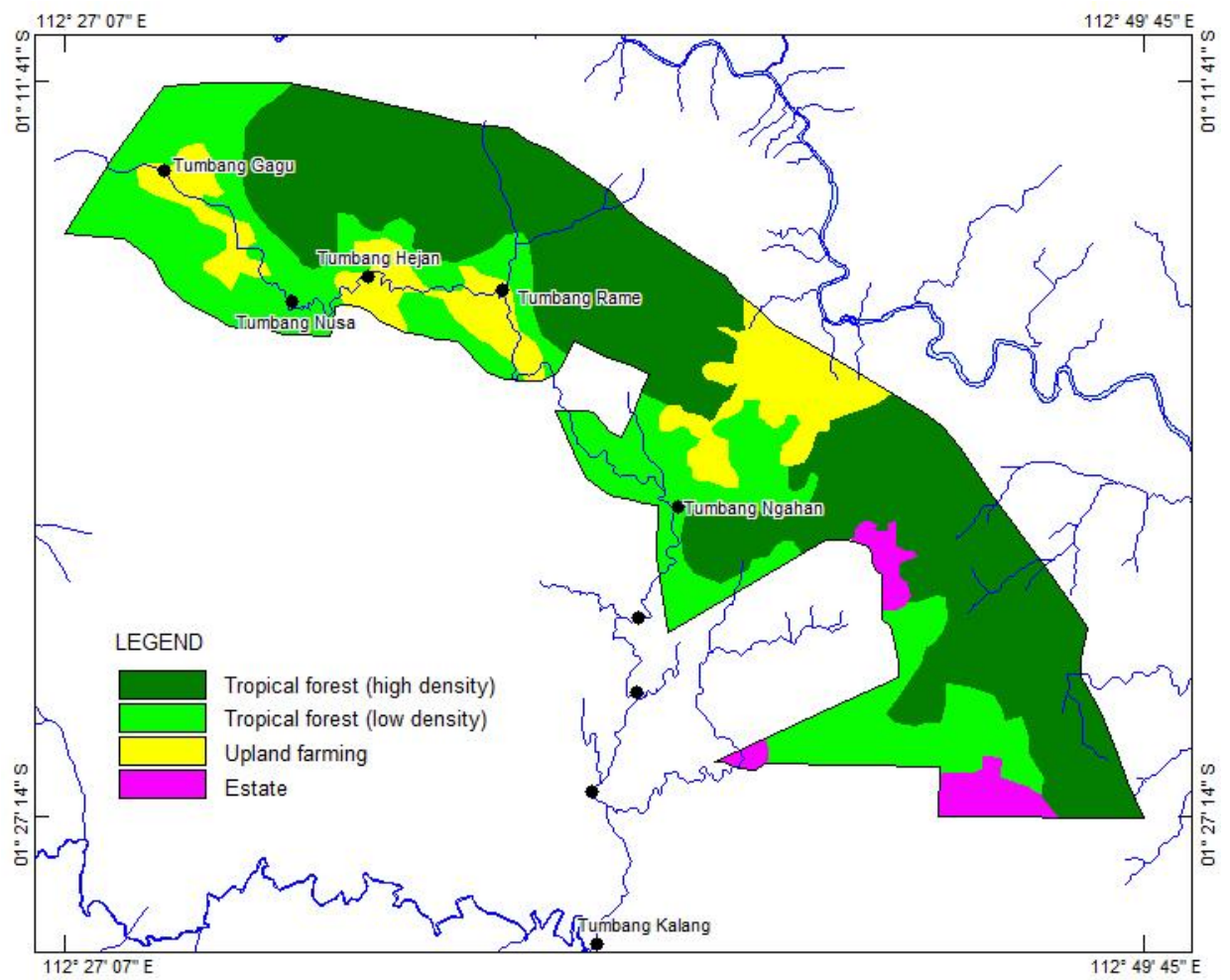

Figure 6. The map of land cover showing present land-use in the study area

\section{Land Cover and Vegetation}

Spatial identification of land cover including the specific location of vegetation used mainly RS technology based on land satellite imagery of Landsat 8 on March and April 2015 considering the minimum cloud cover percentage in order to obtain best GeoTiff format images. The result of Landsat imagery interpretation was then integrated into GIS environment as shown in Figure 6 that represent land cover and present land-use of the study area. At present, the land is still mainly covered by forest including high-density bush with total areas 29,056 hectares or $74.55 \%$ of whole areas of a site study. It indicates that the lands are still available for general land-use.

However, in the south, it has been identified that there are several parts of areas that have been cultivated for the estate. Based on the ground survey, several cultivated lands are a land expansion of oil palm plantation that has been existed in the southern part for several years ago. Land conversion impact to the existing natural environment is, therefore, should be taken into account for future landuse because these sloping land areas are still covered by natural vegetation.

Figure 6 also shows that upland farming has been practiced through opening new land for shifting cultivation. It covers only 8,760 hectares (22.47\%). Although the land has been opened for agricultural practice, the local farmer still uses traditional technique through their indigenous knowledge. For instance, based on the ground survey, they opened the land at undulating plains with slope class less than $8 \%$. In this case, the aspect of conservation has been fulfilled during farming practice.

\section{DISCUSSION}

\section{Land and Environment Degradation}

Land is an important aspect in the natural environment. In addition to soil, slope, as part of landform, is one of several factors 
that determine the type of agriculture (Altieri, 1987) so that it should be considered in agricultural land-use planning (de Lima, 1988). In this study, slope information was used not only as one of several factors in the USLE prediction model but it also was used to determine land suitability classification in land evaluation.

The potency of soil erosion is then should be early known through erosion risk level classification. The result of calculating data input according to the USLE erosion prediction model shown that there are 3 classes of erosion risk level in the study area. Each class reflects the level of erosion risk through soil loss potential (ton hectare $e^{-1}$ year $^{-1}$ ), total areas (Table 2) and spatial distribution (Figure 7).

Table 2 and Figure 7 explain that the lowest potential of erosion risk in site study is class II with average soil loss potential 32.79 ton hectare ${ }^{-1}$ year $^{-1}$. This class occupies $51.63 \%$ $(20,123$ hectares) of the total study area located geographically in the southern spreading to the central part. On the other side, it is also found in the northern part. This region can then be allocated for agricultural practice. However, because the value of soil loss potential appears, both soil and environment conservation intervention measures should be implemented.

Table 2. The classification of the erosion risk potential in the study area

\begin{tabular}{|c|c|c|c|c|c|}
\hline \multirow[t]{2}{*}{ No } & \multirow[t]{2}{*}{ Class } & \multirow{2}{*}{$\begin{array}{l}\text { Soil loss potential } \\
\text { (ton/hectare/year) }\end{array}$} & \multirow{2}{*}{$\begin{array}{l}\text { The average of USLE model } \\
\text { calculation results } \\
\text { (ton hectare } \text { year }^{-1} \text { ) }\end{array}$} & \multicolumn{2}{|c|}{ Total area } \\
\hline & & & & (Hectares) & (\%) \\
\hline 1 & II & $15-60$ & 32.79 & 20,123 & 51.63 \\
\hline 2 & III & $60-180$ & 72.91 & 938 & 2.41 \\
\hline 3 & IV & $180-480$ & 459.28 & 17,913 & 45.96 \\
\hline
\end{tabular}

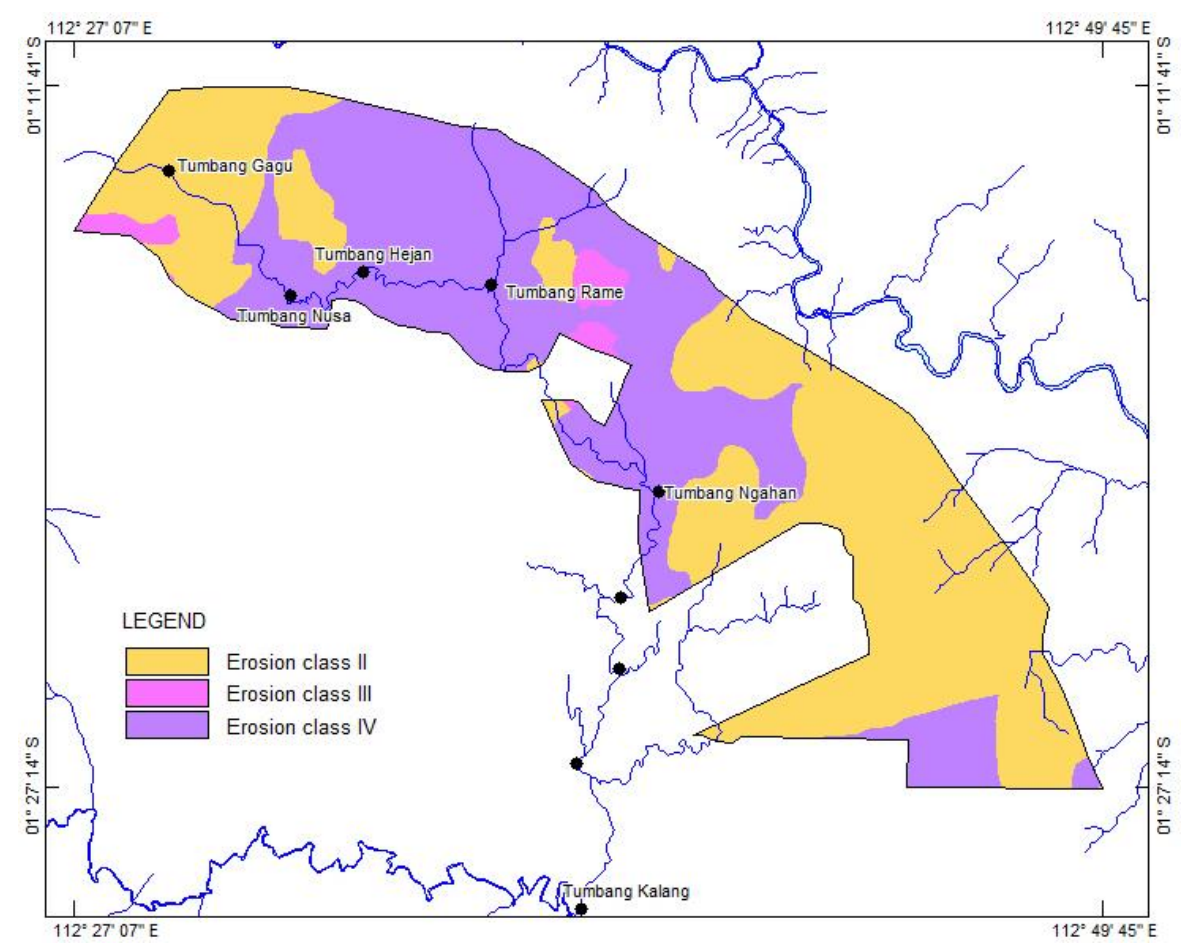

Figure 7. The map of erosion risk potential classification in the study area 
Originally, located in humid tropical regions, the whole areas of Antang Kalang in which the study area take place is endowed by a large area of tropical forest (Rahu et al., 2013). In Kalimantan, on a larger scale of typical lowland rainforest, there are almost 180 tree species hectare ${ }^{-1}$ (Kartawinata et al., 1981). During the field survey, in addition to giant species of Shorea spp, the other plants that have been found are local rubber (Hevea brasiliensis). Along the river stream, some local orchid species were also found beside other species of ornamental plants. The existing of land cover involving crop growth data as well as cropping patterns and land-use contributes to USLE erosion prediction model through the value of vegetation practice (Angima et al., 2003; Wischmeier \& Smith, 1978).

\section{Land Suitability for Farming Practice and Genetic Resource Preservation}

The availability of arable land is the potency of land resource that can be used for human living. However not all the lands can be used optimally because of their limiting factors. Land evaluation approach was then used in this study to determine land suitability classification for several existing crops in certain areas. The importance of land resources evaluation for better agricultural land-use and sustainable agriculture become more clear since it has taken environmental control into account and an efficient land-use that does not degrade the land resources can be achieved (Sharu et al., 2013; Kumar et al., 2017).

Two selected crops based on local existing commodities consists of upland rice and rubber have used for evaluation. In fact, upland rice farming has been practicing by local farmers to meet the basic need of food in these areas. While, for rubber, it has been cultivated since they leave the land to open the other areas. The benefit of extra income taken from rubber tapping has also been widely understood by the local community in this study area.

The result of land resource evaluation provides information that both upland rice and rubber were classified into marginally suitableS3 due to limiting factors of nutrient retention such as $\mathrm{pH}$ and base saturation (Figure 8). However, this condition can be solved through proper improvement. Further evaluation to determine potential land suitability after improvement describe that both rubber and upland rich can reach the higher suitability class become highly suitable-S1. Land allocation for each crop was then justified according to the priority of the needs. Therefore, mainly on the basis of land suitability, landform and existing cultivated land, the most suitable lands for rubber and upland rice is located on undulating plains with slope class $4-8 \%$ meanwhile at slope $16-25 \%$, the lands are not recommended to be cultivated because of marginally suitable-S3 for both of crops. The map of land suitability as a result of the land evaluation is shown in Figure 8.

In order to ensure optimum yield on a sustained basis and conserve the natural environment, the result of the land evaluation was then further integrated into erosion risk potential data. The GIS application through an overlay technique was used to provide new layer information (O'Sullivan \& Unwin, 2003). In this study, land suitability map was then overlayed to erosion risk potential map to produce spatial information about the appropriate land allocation for farming practices and natural environment preservation. The result of spatial analysis shown that most suitability of the land for selected crops occupy the region with the lowest of erosion risk potential (Figure 7 and 9). As a result, spatial information of land-use allocation was then developed as shown in Figure 9. It describes that recommended 
agricultural land-use planning can be implemented in the southern, central and northern part of the study area with total area 9,039 hectares (23.19\%). However, because the potential of erosion risk has already occurred, indicated with risk potential class of II (soil loss potential 15-60 ton hectare ${ }^{-1}$ year $^{-1}$ ), the aspect of conservation should be integrated during agricultural practices. Among the villages located in the study area, Tumbang and Tumbang Ngahan can be a priority for initial agricultural development program because they are geographically located in the agricultural land region. For Tumbang Ngahan, although it lies near arable land for agriculture, it strategically considered as main gate access to enter site location.

In the case of Antang Kalang, related to conservation aspects, an initial step toward sustained land-use and environment preservation changes the concept of shifting cultivation to permanent cultivation. Basically, the negative environmental impact of shifting cultivation includes any changes in soil physical and chemical properties and changes in soil nutrient status leading to land and forest degradation and environmental damage (Stadtmueller, 1990; Salinas-Melgoza et al., 2017). Furthermore, deforestation, as part of opening the lands in this traditional system or even modern agriculture and other activities such as illegal logging leads to a direct loss of biodiversity (Jeus et al., 2012).

On the other side, the non-arable lands covering almost 29,934 hectares $(76.81 \%)$ can be recommended for forest preservation. The existence of tropical biodiversity that plays an important part in environmental balance is then should be a priority especially at sloping lands that have high susceptibility of land degradation.

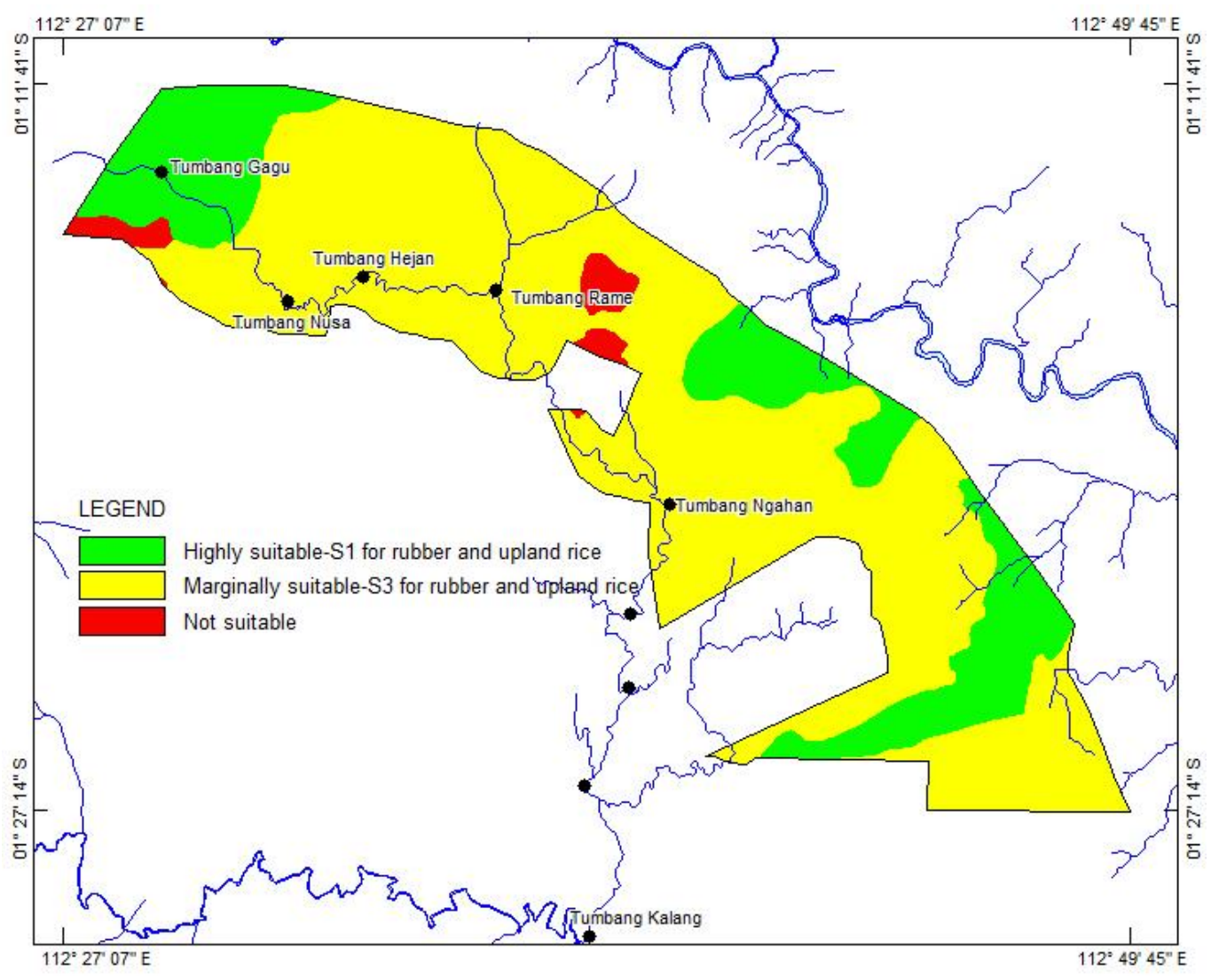

Figure 8. The map of land suitability for rubber and upland rice in the study area 


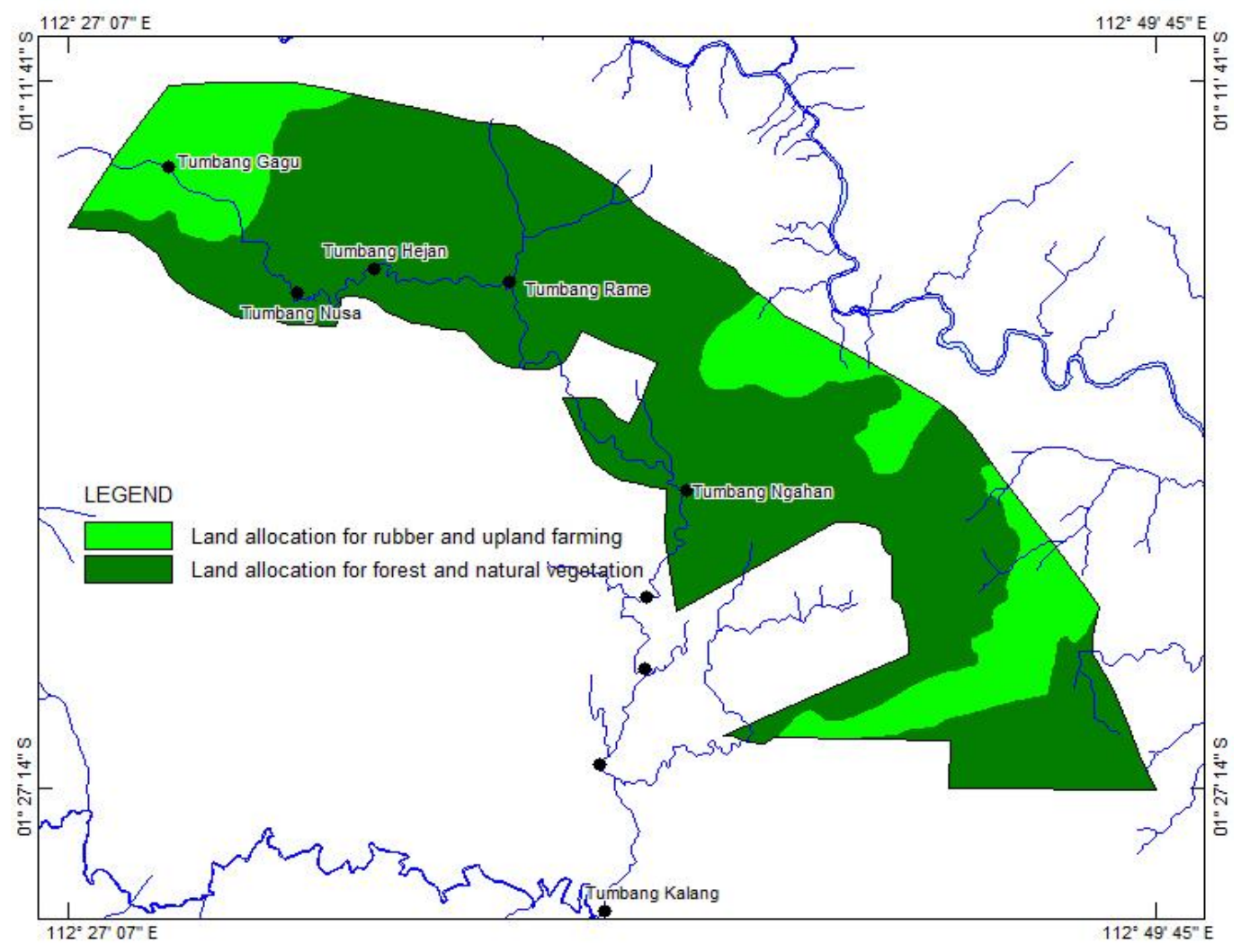

Figure 9. The map of land allocation for farming practices and forest in the study area

In the study area and its surrounding, local plants, wildlife, plants, and animals were still found. Natural resource that could be direct or indirect used involve goods and service such as species for food, medicine and buildings material as well.

As a final result, spatial information about land allocation based on land resource and its natural resources can then be used as basic consideration for land-use planning at sloping lands that have permanent limiting factors for agricultural practice and other relevant activities related to land conversion in the future. The aspect of conservation should be integrated into sloping lands management. Intercropping of rubber and upland rice could be an option that can be implemented for farming practice (Simpson, 2010).

\section{CONCLUSION}

The concept of land suitability derived from land evaluation and USLE erosion prediction model can be used for environmental spatial management to determine the land-use allocation of the agricultural land region and natural environment areas precisely. In order to provide relevant information within spatial data, the use of geographic information system (GIS) and remote sensing (RS) technology is required in displaying data, interpretation and spatial analysis.

\section{ACKNOWLEDGMENTS}

The authors wish to thank Prof. Dr. Zulkifli Zaini as a team leader who contributes both thought and funds. In addition, also thank PT. Poyry Indonesia for any relevant data required in this study. Any remaining errors or omissions will be responsibility accepted by the authors.

\section{REFERENCES}

Abdel Rahman, M. A. E., Natarajan, A., \& Hegde, R. (2016). Assessment of Land Suitability and Capability by Integrating 
Remote Sensing and GIS for Agriculture in Chamarajanagar District, Karnataka, India. The Egyptian Journal of Remote Sensing and Space Science, 19(1), 125-141. https://doi.org/10.1016/j.ejrs.2016.02.001

Altieri, M. A. (1987). Agroecology, The Scientific Basis of Alternative Agriculture. Boulder, Colorado, US: Westview Press.

Altieri, M. A. (1992). Agroecological Foundations of Alternative Agriculture in California. Agriculture, Ecosystems and Environment, 39(1-2), 23-53. https://doi.org/10.1016/01678809(92)90203-N

Amien, L. I. (1990). Utilization of Acid Tropical Soils for Sustainable Agriculture. Indonesian Agricultural Research and Development Journal, 12(2), 17-22.

Andy, B., Hamdan, J., Anuar, A. R., \& Peli, M. (2002). Determination of Agricultural Land Regions Using Agroecological Zone (AEZ) Approach and Geographic Information System (A case study of Kotawaringin Barat Regency, Kalimantan, Indonesia). Proceeding of The Malaysian Society of Soil Science Conference 2002: Applications of Modern Tools in Agriculture, 36-40. Serdang, Selangor, Malaysia: Malaysian Society of Soil Science.

Angi, E. M., \& Wiati, C. B. (2017). Kajian Ekonomi Politik Deforestasi dan Degradasi Hutan dan Lahan di Kabupaten Paser, Kalimantan Timur. Jurnal Penelitian Ekosistem Dipterokarpa, 3(2), 63-80.

Angima, S. D., Stott, D. E., O'Neill, M. K., Ong, C. K., \& Weesies, G. A. (2003). Soil Erosion Prediction Using RUSLE for Central Kenyan Highland Conditions. Agriculture, Ecosystems and Environment, 97(1-3), 295-308.

https://doi.org/10.1016/S01678809(03)00011-2

BPS Provinsi Kalimantan Tengah. (2017). Provinsi Kalimantan Tengan dalam Angka (Kalimantan Tengan Province in Figures). Palangka Raya, Indonesia: BPS Provinsi Kalimantan Tengah.

de Lima, J. L. M. P. (1988). Morphological Factors Affecting Overland Flow On
Slopes. In J. Bouma \& A. K. Bregt (Eds.), Proceedings of the Symposium on Land Qualities in Space and Time (pp. 321324). Wageningen, Netherlands: Wageningen. PUDOC.

Espinosa, J., López-Olvera, J. R., Cano-Manuel, J. F., Fandos, P., Pérez, J. M., LópezGraells, C., ... Granados, J. E. (2017). Guidelines for Managing Captive Iberian Ibex Herds for Conservation Purposes. Journal for Nature Conservation, 40, 24-32. https://doi.org/10.1016/j.jnc.2017.09.002

Eswaran, H., Kimble, J., Cook, T., \& Beinroth, F. H. (1992). Soil Diversity in the Tropic: Implications for Agricultural Development. In Myths and Science of Soils of the Tropics (SSSA Speci, pp. 1-16). Madison, Wisconsin, USA: Soil Science Society of America and American Society of Agronomy.

FAO. (1976). A Framework for Land Evaluation (Soils Bull). Rome, Italy: FAO.

Flaherty, M., \& Smit, B. (1982). An Assessment of Land Classification Techniques in Planning for Agricultural Land Use. Journal of Environmental Management, 15, 323-332.

Garcia, G. A., Rosas, E. P., García-Ferrer, A., \& Barrios, P. M. (2017). Multi-Objective Spatial Optimization: Sustainable Land Use Allocation at Sub-Regional Scale. Sustainability, 9(927), 1-21. https://doi.org/10.3390/su9060927

Gay-des-Combes, J. M., Carrillo, C. S., Robroek, B. J. M., Jassey, V. E. J., Mills, R. T. E., Arif, M. S., ... Buttler, A. (2017). Tropical Soils Degraded by Slash-and-Burn Cultivation can be Recultivated When Amended with Ashes and Compost. Ecology and Evolution, 7(14), 5378-5388. https://doi.org/10.1002/ece3.3104

Goodchild, M., Robert, H., \& Stepen, W. (1992). Integrating GIS and Spatial Data Analysis: Problem and Possibilities. Geographical Information Systems, 6(5), 407-423. https://doi.org/10.1080/02693799208901923

Hoffman, M. (2017). The Role of Public Land Use Planning in Facilitating Conservation on Private Land. Natural Areas Journal, 37(4), 556-563.

Jeus, M., Henriques, P., Laranjeira, P., Narciso, 
V., \& da Silva Carvalho, M. L. (2012). The Impact of Shifting Cultivation in the Forestry Ecosystems of Timor-Leste (No. 2012/16). Évora, Portugal.

Kartawinata, K., Abdulhadi, R., \& Partamiharjo, T. (1981). Composition and Structure of a Lowland Dipterocarp Forest at Wanariset, East Kalimantan. Malaysian Forester, 44, 397-406.

Kumar, A., Mahapatra, S. K., Lal, T., Yadav, R. P., \& Singh, S. K. (2017). Land Evaluation for Land Use Planning towards Sustainable Crop Production: A Case Study of Chhata tehsil in Mathura District, Uttar Pradesh, India. International Journal of Current Microbiology and Applied Sciences, 6(9), 859-870.

Loo, Y. Y., Billa, L., \& Singh, A. (2015). Effect of Climate Change On Seasonal Monsoon In Asia and Its Impact On The Variability of Monsoon Rainfall in Southeast Asia. Geoscience Frontiers, 6(6), 817-823. https://doi.org/10.1016/j.gsf.2014.02.009

Mulyoutami, E., van Noordwijk, M., Sakuntaladewi, N., \& Agus, F. (2010). Perubahan Pola Perladangan: Pergeseran Persepsi Mengenai para Peladang di Indonesia. Bogor, Indonesia: World Agroforestry Centre.

Notohadiprawiro, T. (1989). Farming Acid Mineral Soils for Food Crops: an Indonesian Experience. In E. T. Craswell \& E. Pushparajah (Eds.), Management of Acid Soils in the Humid Tropics of Asia (pp. 62-68). Canberra, Australia: Australian Centre for International Agricultural Research.

O'Sullivan, D., \& Unwin, D. J. (2003). Geographic Information Analysis. Hoboken. New Jersey, USA: John Wiley \& Sons, Inc.

Rahu, A. A., Hidayat, K., Ariyadi, M., \& Hakim, L. (2013). Ethnoecology of Kaleka: Dayak's Agroforestry in Kapuas, Central Kalimantan Indonesia. Research Journal of Agriculture and Forestry Sciences, 1(8), 5-12.

Salinas-Melgoza, M. A., Skutsch, M., Lovett, J. C., \& Borrego, A. (2017). Carbon Emissions from Dryland Shifting Cultivation: a Case Study of Mexican
Tropical Dry Forest. Silva Fennica, 51(1B), 1-25. https://doi.org/10.14214/sf.1553

Sharu, M. B., Yakubu, M., Noma, S. S., \& Tsafe, A. I. (2013). Land Evaluation of an Agriculture Landscape in Dingyadi District, Sokoto State, Nigeria. Nigerian Journal of Basic and Applied Science, 21(2), 148-156.

Simpson, L. A. (2010). A Manual of Soil Conservation and Slope Cultivation, Mainstreaming and Capacity Building for Sustainable Land Management (PIMS 3409-). Port of Spain, Trinidad and Tobago.

Sitanggang, G. (2010). Kajian Pemanfaatan Satelit Masa Depan: Sistem Penginderaan Jauh Satelit LDCM (Landsat8). Berita Dirgantara, 11(2), 47-58.

Smith, B., \& Sandwell, D. (2003). Accuracy and Resolution of Shuttle Radar Topography mission data. Geophysical Research Letters, $\quad 30(9), \quad 1467$. https://doi.org/10.1029/2002GL016643, 2003

Stadtmueller, T. (1990). Soil Erosion in East Kalimantan, Indonesia. Proceedings of The Fiji Symposium: Research Needs and Applications to Reduce Erosion and Sedimentation in Tropical Steeplands, 221230. Wallingford, UK: IAHS-AISH Publ.

Suharta, N. (2010). Karakteristik dan Permasalahan Tanah Marginal dari Batuan Sedimen Masam di Kalimantan. Jurnal Litbang Pertanian, 29(4), 139-146. https://doi.org/10.21082/jp3.v29n4.201 0.p139-146

Sys, C., Van Ranst, E., Debaveye, J., \& Beernaert, F. (1993). Land Evaluation. Part III. Crop requirements. Agricultural Publication No. 7. Brussels, Belgium: GADC.

Tomlinson, R. F. (1968). A Geographical Information System for Regional Planning. CSIRO Symposium, 200-210. Macmillan, Australia: UNESCO.

van Uexkull, H. R., \& Bosshart, R. P. (1989). Management of Acid Upland Soils in Asia. In E. T. Craswell \& E. Pushparajah (Eds.), Management of Acid Soils in the Humid Tropics of Asia (pp. 2-19). Canberra, Australia: Australian Centre for International Agricultural Research. 
Wahyunto, Hikmatullah, Suryani, E., Tafakresnanto, C., Ritung, S., Mulyani, A., ... Nuryamsi. (2016). Petunjuk Teknis: Pedoman Penilaian Kesesuaian Lahan Untuk Komoditas Pertanian Strategis. Bogor, Indonesia: Balai Besar Litbang Sumberdaya Lahan Pertanian.

Wischmeier, W. H., \& Smith, D. D. (1978).
Predicting Rainfall Erosion Losses, A Guide to Conservation Planning (Handbook N). Washington, USA: United States Government Printing Office.

Wohl, E., Barros, A., Brunsell, N., Chappell, N. A., Coe, M., Giambelluca, T., ... Ogden., F. (2012). The Hydrology of the Humid Tropics. Nature Climate Change, 2, 655-662. 